\title{
PENYEBARAN INFORMASI KEPADA STAKEHOLDERS MELALUI PENGELOLAAN CYBER PR TVRI SULAWESI TENGAH (SULTENG)
}

\author{
Rizqy Alfiyaty, Ilyas Lampe, Fitri \\ Program Studi Ilmu Komunikasi FISIP Universitas Tadulako \\ Email: rizqyalfiyaty@gmail.com
}

\begin{abstract}
ABSTRAK
Tujuan penelitian ini untuk mengetahui pengelolaan cyber PR TVRI Sulteng dalam menyebarkan informasi kepada stakeholders. Metode penelitian yang digunakan adalah kualitatif, dengan teknik penentuan informan menggunakan metode purposive sampling yang melibatkan empat (4) informan. Metode pengumpulan data yang digunakan yaitu observasi, wawancara mendalam dan dokumentasi. Sedangkan teknik analisis data yang digunakan adalah reduksi data, penyajian data, dan verifikasi/penarikan kesimpulan. Hasil penelitian menunjukkan bahwa pengelolaan cyber PR TVRI Sulteng dalam memberikan informasi kepada stakeholders internal menggunakan transparansi jenis radical transparency yaitu dimana seluruh data, argumen dan hal terkait pergerakan serta keputusan perusahaan disebarkan kepada internal perusahaan. Pengelolaan cyber PR TVRI Sulteng dalam memberikan informasi kepada stakeholders eksternal menggunakan transparansi jenis controlled transparency yaitu informasi yang disebarkan oleh perusahaan ke publik melalui internet dilakukan secara terkontrol, kedua richness in content yaitu kekayaan konten yaitu penciptaan konten yang kaya berupa kata-kata, gambar, suara, video, diagram, musik dan lain-lain disediakan untuk publik dan ketiga adalah reach dimana perusahaan mengaktifkan media sosialnya yaitu facebook, intagram, youtube, website, dan twitter serta menyediakan hyperlink exchange dan search engine optimization sebagai usaha untuk menjangkau publik.
\end{abstract}

\section{Kata Kunci : Pengelolaan; Cyber PR; Stakeholders; TVRI Sulteng}

Submisission: 26 April 2021

\begin{abstract}
Pendahuluan
Pesatnya perkembangan dan pemanfaatan teknologi komunikasi, khususnya internet mengubah cara manusia dalam memperoleh informasi. Menurut data dari Kementerian Komunikasi dan Informatika Republik Indonesia (Kemenkominfo RI), Indonesia menempati posisi ke-8 penggunaan internet terbanyak di dunia (Budhi, 2016).

Data terbaru juga dilaporkan oleh $\mathrm{We}$ Are Social tahun 2020 yang menyebutkan bahwa dari total populasi Indonesia yang jumlahnya 272,1 juta jiwa, kurang lebih ada
\end{abstract}

$64 \%$ diantaranya sudah terkoneksi dengan jaringan internet. Jumlah pengguna internet di Indonesia meningkat 17\% dari tahun 2019 ke tahun 2020 (https://m.detik.com).

Kehadiran internet melahirkan media sosial sebagai platform interaksi dan berbagi informasi memunculkan satu media baru bagi praktisi PR atau Humas dalam menjalankan aktivitas keseharian. Tidak hanya menggunakan media konvensional dalam menjalin relasi, saat ini PR/Humas dituntut untuk beradaptasi dengan hadirnya new media. e-PR yang biasa disebut $C y b e r$ $P R$ merupakan cara yang dilakukan oleh 
PR/Humas dalam menjalin hubungan dengan khalayaknya menggunakan media internet (Yuliawati \& Enjang, 2016: 212). Berubahnya pola interaksi masyarakat di berbagai bidang baik bisnis, ekonomi, sosial dan budaya akibat internet menuntut perusahaan, termasuk TVRI Sulteng melakukan transformasi dalam penyebaran inormasi kepada stakeholders baik internal maupun eksternal.

Penelitian terdahulu membuktikan bahwa penggunaan cyber PR menimbulkan dampak yang positif baik bagi perusahaan maupun instansi yang menjalankannya. Beberapa manfaat menggunakan cyber PR adalah adanya komunikasi yang konstan serta respon yang cepat.(Qur'ani Dewi Kusumawardani, 2016 dan Dhia Oktafian Kuldias Putri, 2019).

Pemanfaatan Cyber $P R$ oleh TVRI Sulteng terlihat dari pemanfaatan beberapa media sosial, seperti facebook, instagram, youtube dan twitter melengkapi website yang telah ada sebelumnya. Keberadaan media komunikasi secara online ini, diharapkan makin melengkapi pemanfaatan media komunikasi konvensional yang telah ada sebelumnya. Hal ini tentu akan mempengaruhi proses pengelolaan penyebaran informasi kepada stakeholders oleh PR/Humas TVRI Sulteng.

\section{Tinjauan Pustaka Definisi Public Relations}

Berbicara

mengenai public relations

(PR) atau Hubungan Masyarakat, artinya kita

berbicara mengenai bagaimana sebuah perusahaan, organisasi atau institusi berkomunikasi dengan publiknya. PR sebagai fungsi

manajemen yang memiliki tugas

merancang strategi komunikasi bukan hanya untuk

memberikan informasi perusahaan tetapi juga harus mampu membangun sebuah brand dari perusahaan tersebut. Secara umum Public relations melakukan komunikasi untuk menciptakan hubungan baik sehingga tumbuh citra positif terhadap merek perusahaan (Aprilia et al., 2020).

Praktek penyelenggaran hubungan masyarakat dalam organisasi-organisasi mungkin dilakukan dengan cara berbedabeda. Perbedaan tersebut terkait posisi humas (public relations) dalam organisasi, karena ada organisasi yang menjalankan fungsi humas terpisah dengan fungsi lain, dan ada yang menjadi satu bagian. Fungsi public relations menurut Cutlip, Center dan Broom (Putra, 1999: 8-9) dibedakan menjadi 2 jenis, yaitu fungsi manajemen dan fungsi komunikasi. Praktisi yang menjalankan fungsi manajemen bertugas menyusun kebijakan, dan bertanggungjawab terhadap konsekuensi yang muncul. Dalam hal ini praktisi public relations berperan menjadi penasehat manajemen dalam mengambil kebijakan yang tepat dan diterima publik. Sedangkan public relations sebagai fungsi komunikasi adalah staf khusus yang melayani para pemimpin organisasi, khususnya membantu dalam berkomunikasi dengan public (Anwar, 2015).

Definisi PR menurut Effendy adalah komunikasi dua arah dengan publik secara timbal balik dalam rangka mendukung fungsi dan tujuan manajemen dengan meningkatkan pembinaan kerja sama dan pemenuhan kepentingan bersama (Sumarto, 2016: 66). Menurut penelitian Van Dyke dan Verčič (2009), komunikasi diibaratkan seperti urat nadi penghubung kehidupan, sebagai salah satu ekspresi dari karakter, sifat atau tabiat seseorang untuk saling berinteraksi, mengidentifikasikan diri serta bekerjasama (Sukoco, 2014). PR juga harus mampu merancang sistem komunikasi sekaligus media komunikasi yang 
menyertainya baik cetak, elektronik maupun online media (Gani, 2015: 27).

Definisi lain juga dikemukakan Rumanti, public relations adalah profesi yang professional dalam berinteraksi untuk mencapai tujuan dengan cara cepat dan tepat serta terjadi terus menerus sehingga terbentuk opini publik yang menguntungkan kedua belah pihak (Rumanti, 2002:7). Berdasarkan definisi diatas disimpulkan bahwa PR adalah sebuah profesi yang profesionalitas dalam membangun dan mempertahankan komunikasi dua arah yang sudah terencana melalui media cetak, elektronik, serta media online baik itu ke dalam maupun keluar perusahaan/organisasi untuk mencapai tujuan dan saling pengertian.

\section{Fungsi dan Peran Public Relations}

Fungsi utama $P R$ adalah bertindak sebagai komunikator yang menganalisa peluang dan tantangan yang akan muncul kemudian melakukan problem solving, membangun atau membina hubungan (relationship) yang positif dan baik dengan pihak publik sebagai target sasaran komunikasi dalam program PR, peranan back up management.

Fungsi $P R$ melekat pada fungai manajemen POAC yaitu Planning (Perencanaan), Organizing (Pengorganisasian), Actuating (Penggerakkan), dan Controlling (Pengawasan), menciptakan citra perusahaan atau lemabaga (corprate image) yang merupakan tujuan akhir dari suatu aktivitas program kerja $P R$ campaign, baik untuk keperluan publikasi maupun promosi (Daymon Christine, 2008: 5).

Sedangkan peran utama $P R$ adalah sebagai komunikator atau penghubung antara organisasi atau lembaga yang diwakili dengan publiknya, sebagai pembina relationship, yaitu berupaya membina hubungan yang positif dan saling menguntungkan dengan pihak publiknya, sebagai peranan back up management, yakni sebagai pendukung dalam fungsi dan manajemen organisasi atau perusahaan, sebagai pembentuk corporate image, artinya peranan PR berupaya menciptakan citra bagi organisasi atau lembaganya (Ruslan, 2007: 10). Seorang PR membutuhkan alat untuk menunjang tercapainya tujuan, diantaranya iklan, pameran, media internal, fotografi, film, Pers, serta internet (Hairunnisa, 2015: 54-62).

\section{Cyber Public Relations}

Membahas tentang cyber PR ada beberapa nama lain yang sering digunakan diantaranya e-PR, online PR, media baru, online media, dan lain sebagainya. Secara umum bahwa e-PR adalah kependekan dari kata elektornic, public, dan relation. Secara terminologi menurut Onggo, e-PR adalah inisiatif PR yang menggunakan media internet sebagai sarana publisitas (Basit \& Rahmawati, 2017:202).

Definisi lain juga mengatakan bahwa media baru merupakan "tempat" di mana seluruh pesan komunikasi terdesentralisasi dan keterlibatan audiens dalam proses komunikasi yang semakin meningkat (McQuail, 2010:130).

Setiap perusahaan tidak akan terlepas dari konsep 3R (Putri 2019:31-32), yaitu, Relations artinya mampu berinteraksi dengan berbagai target audiens untuk membangun hubungan dan citra perusahaan. Reputasi yaitu aset yang paling penting dalam suatu bisnis. Cyber PR merupakan suatu seni dalam membangun reputasi online secara berkesinambungan. Serta Relevansi yaitu mengupayakan agar kegiatan inisiatif PR secara online relevan dengan target publik korporat. 
Aktivitas Cyber Public Relations

e-PR yang biasa disebut Cyber PR merupakan cara yang dilakukan oleh PR untuk menjalin hubungan dengan khalayaknya dengan menggunakan media internet (Yuliawati \& Enjang, 2016: 212). Dalam cyber PR ada beberapa potensi yang bisa dimanfaatkan seorang praktisi PR melalui media internet, yaitu :

a. Komunikasi konstan, dengan internet yang terus beraktivitas dalam jangka waktu selama 24 jam menghasilkan potensi interaksi dengan target publik di seluruh dunia.

b. Respon yang cepat, memungkinkan secara cepat merespon semua permasalahan dan pernyataan dari publik dan pelanggan.

c. Pasar global internet telah menutup jurang pemisah geografis. Melalui internet, pebisnis dapat berkomunikasi ke berbagai negara dengan biaya yang sangat minim.

d. Interaktif, dengan adanya internet membuat para pebisnis mampu memahami apa yang diinginkan pelanggan dari respon yang diberikan melalui situs web yang tersedia.

e. Komunikasi dua arah, internet mampu membangun hubungan yang kuat antara organisasi dan publik.

f. Hemat, e-PR dianggap lebih dapat mempengaruhi tanggapan dan respon pasar dengan lebih cepat. Pengeluarannya pun lebih hemat dibanding pengeluaran iklan karena tidak membutuhkan biaya cetak.

\section{Elemen dasar Cyber Public Relations}

Phillips dan Young (2009:37)
menjelaskan bahwa dalam mencapai
kesuksesan praktik PR secara online,
terdapat lima elemen dasar online PR yang
harus diperhatikan oleh para praktisi PR
yaitu:

Transparency yang terdiri dari radical transparency, controlled transparency, institutional transparency, overt transparency, covert transparency, unintentional transparency.

Internet Porosity yaitu transparansi yang tidak disengaja. Saat ini, perusahaan banyak melakukan komunikasi menggunakan internet seperti melalui email, instant messaging, blogs, dan social media. Ketika perusahaan memulai interaksi kepada pihak eksternal melalui dunia maya, informasi mengenai perusahaan akan disebarkan dengan cara yang lebih informal dan lebih transparan. Karena itu, beberapa informasi yang seharusnya tidak dipublikasikan dapat lebih mudah bocor ke khalayak karena mudahnya akses tersebut.

The Internet as an Agent yaitu proses transformasi pesan di mana pesan tersebut diberikan dari satu orang ke orang yang lain secara online, yang kemudian memberikan konteks dan pemahaman baru.

Richness in Content yaitu kekayaan informasi yang tercipta dan tersampaikan karena adanya reach dalam internet. Terdapat dua area perkembangan richness atau kekayaan informasi, pertama dalam penciptaan konten yang kaya yaitu adanya berbagai macam bentuk konten seperti katakata, gambar, suara, video, diagram, musik, dan lain-lain yang disediakan untuk publik dan teknologi internet. Area yang kedua adalah keterlibatan orang-orang yang akan menambahkan kekayaan melalui komunitas online mereka sendiri, yang kemudian akan berpengaruh pada bertambahnya richness dan reach dalam proses yang bersimbiosis. Hal ini bisa tercapai dengan berbagai cara, seperti melalui blog, forum, serta melalui perkembangan sumber online yang membuat konten-konten.

Reach atau jangkauan publik terhadap konten dapat diciptakan melalui berbagai cara. Perusahaan bisa melakukan beberapa teknik agar halaman website 
perusahaan dapat dengan mudah ditemukan oleh publik, seperti dengan search engine optimization dan hyperlink exchange.

\section{Stakeholders}

Stakeholders adalah setiap kelompok yang berada di dalam maupun di luar perusahaan yang mempunyai peran dalam menentukan keberhasilan suatu perusahaan (Kasali, 1994: 63). Secara umum stakeholders dikelompokkan menjadi dua bagian, yaitu :

1. Stakeholders Internal (Elvinaro, 2008: 124) yang terdiri dari

a. Pemegang saham : atau biasa dibilang pemilik perusahaan yang mempunyai kekuasaan sangat besar.

b. Manajer dan Top Executive : manajer berada dibawah kendali pemilik

c. Karyawan : orang-orang dalam perusahaan yang tidak memegang jabatan struktural

2. Stakeholders Eksternal adalah mereka yang berkepentingan terhadap perusahaan, dan berada diluar perusahaan. Terdiri dari :

a. Pemerintah : penentu kebijakan

b. Pers : media yang memiliki pengaruh pada masyarakat.

c. Komunitas : masyarakat yang tinggal, hidup, dan berusaha di sekitar lokasi suatu perusahaan

\section{Metode Penelitian}

Penelitian ini menggunakan tipe kualitatif dengan dasar penelitian yaitu studi kasus. Lokasi penelitian di Jl. Undata No. 1, Kota Palu, Sulawesi Tengah. Menurut Ardianto (2010:64) studi kasus merupakan penelitian yang dilakukan secara intensif, mandalam, mendetail dan komprehensif bisa dilakukan terhadap individu, kelompok, organisasi, dan lingkungan sekitar. Subjek dalam penelitian ini ada empat (4) informan yang dipilih melalui teknik purposive sampling.
Jenis data yang digunakan terdiri dari data pimer dan sekunder. Sementara untuk teknik pengumpulan data peneliti melakukan observasi, wawancara dan dokumentasi. Kemudian peneliti memilah data yang telah diperoleh melalui hasil wawancara dengan informan maupun observasi selanjutnya dikemas dalam penyajian data dimana peneliti mencoba membuat dalam bentuk tabel terkait transkrip wawancara, kemudian menggolongkan, mengarahkan, membuang yang tidak perlu dan mengorganisasikan data dengan cara sedemikian rupa hingga kesimpulan-kesimpulan finalnya dapat ditarik dan diverifikasi. Kemudian dilakukan penarikan kesimpulan berdasarkan data yang telah disajikan terkait dengan pokok bahasan cyber PR kemudian mengaitkannya dengan teori yang sudah ditetapkan oleh peneliti.

\section{Hasil Penelitian}

TVRI Sulteng dalam memberikan informasi kepada internal perusahaan lebih intensif menggunakan whatsapp sebagai media untuk penyebaran berbagai informasi terkait perusahaan. Lain halnya media yang digunakan dalam koordinasi dengan TVRI pusat itu menggunakan email. Hal tersebut dipilih karena lebih memudahkan, efektif dan pemanfataan yang intensif dalam berbagi informasi secara internal.

Pengelolalan cyber PR kepada stakeholders internal diukur menggunakan konsep cyber PR yang dikemukan oleh Phillips \& Young (2009: 37) adalah transparency, internet porosity, the internet as an agent, richness in content, dan reach. Tim IT yang kemudian berperan sebagai praktisi PR menerapakan elemen transparansi yang bersifat radical transparency dimana kebijakan yang bersifat rahasia hanya disebarkan ke internal perusahaan dalam hal ini karyawan, pemegang saham, manajer dan top 
executive. Informasi yang sifatnya rahasia dan terbatas semisal kebijakan strategis dan kompetisi bisnis hanya dibahas di level manajemen lalu hasilnya akan dibagikan kepada karyawan/staf yang berkepentingan. Penerapan empat (4) konsep Cyber PR yang lain tidak diterapkan karena lebih erat kaitannya dengan stakeholders eksternal.

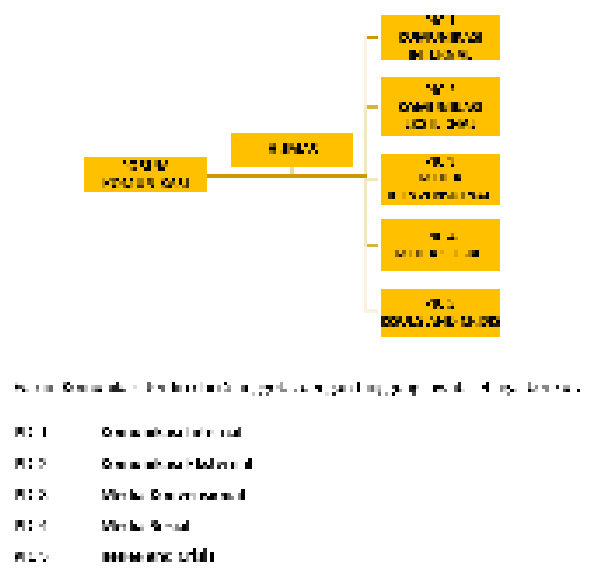

Gambar 1. Forum Komunikasi TVRI

(Sumber : Panduan Komunikasi TVRI)

Pengelolaan cyber PR TVRI Sulteng dalam memberikan informasi kepada stakeholders ekternal mengacu kepada undang-undang karena sebagai lembaga negara, TVRI Sulteng dituntut melakukan filterisasi ataupun penyaringan tayangan dengan tidak menyinggung tentang SARA (Suku, Agama, Ras, dan Antargolongan). Publikasi melalui media sosial ini biasanya akrab disebut dengan cyber PR Cyber PR bergerak sebagai upaya memelihara kepercayaan maupun pemahaman tentang organisasi kepada khalayak yang dilakukan secara interaktif melewati batas penghalang baik ruang ataupun waktu sehingga mempermudah mengirimkan informasi di seluruh dunia.

Cyber PR sangat membantu dalam hal menginformasikan pesan kepada khalayak dengan cepat dan efisien tanpa adanya batasan geografis wilayah tertentu. Disamping itu, TVRI Sulteng dalam memberikan informasi tentunya memiliki data-data internal yang sengaja tidak dipublikasikan pada masyarakat. Proses Pembuatan Konten Cyber PR TVRI Sulteng Kepada Stakeholders Eksternal.

1. Praproduksi (pre-production)

Pembuatan program atau konten pada media sosial merupakan duplikasi dari program acara tayangan TV olehnya tahapannya pembuatan konten media sosial juga berangkat dari ide dari divisi program yang terdiri dari produser dan pengarah acara. Tahapan praproduksi dimulai dengan adanya ide dan planning meeting. Tahap praproduksi tim divisi program yang terdiri dari produser dan pengarah acara serta kru dari divisi teknik melakukan meeting untuk pembuatan program acara/konten. Program acara akan dibuat pada tiga hari setelah meeting dilakukan. Memproduksi sebuah konten khususnya konten cyber PR, TVRI Sulteng dituntut untuk memperhatikan beberapa hal diantaranya logo, warna, latar, tipografi, fotografi, dan supergrafis yang telah diatur dalam buku panduan identitas TVRI

2. Produksi (production)

a. Facebook \& Instagram : Konten dalam facebook dan instagram memuat mengenai informasi iklan tayangan untuk mempromosikan tayangan yang akan datang. Sementara untuk waktu pengiriman kategori konten yang tayang tiap hari paling cepat setengah jam dan paling lambat 5 menit sebelum tayang di TV sudah dikirimkan di media sosial karena mengikut dari waktu datangnya pembawa acara TV, sementara untuk kategori program mingguan paling cepat diupload satu hari sebelum acara tersebut.

b. Youtube : Media sosial youtube dikhususkan untuk mengirimkan video berdurasi panjang yang dibagi 
kedalam beberapa bagian untuk meningkatkan jumlah penonton.

c. Twitter dan Website : Media sosial twitter dan website merupakan media sosial TVRI Sulteng yang tidak melakukan banyak aktivitas di dalamnya. Untuk twitter saat ini terlihat tidak ada postingan di dalamanya dan untuk website hanya digunakan sebagai sarana live streaming baik dari TV maupun dari debat publik.

3. Pasca Produksi

Proses evaluasi dilakukan menggunakan media sosial analisis. Untuk setiap media sosial sudah terdapat sosial media analisis sendiri. Analisis tersebut dapat digunakan untuk mengukur efektivitas media sosial yang digunakan. TVRI Sulteng sudah menggunakan fasilitas yang diberikan berupa instagram insight, facebook inshigt, youtube insight, twitter insight dan website insight. Hasil analisis berdasarkan masing-masing insight dari media sosial yang nantinya akan dirapatkan dan dikelola oleh tim IT TVRI Sulteng untuk diperbaiki pada postingan berikutnya. Saat evaluasi dilakukan, tim IT juga melihat kembali pencapaian yang didapatkan dari media sosial. Melihat mana postingan yang memiliki banyak feedback dan postingan mana yang paling sedikit mendapatkan feedback dari stakeholders. Sehingga tim IT dapat mengetahui dan dapat membenahi postingan berikutnya. Evaluasi ini dilakukan setiap enam bulan sekali. Berikut alur produksi program/informasi TVRI Sulteng.

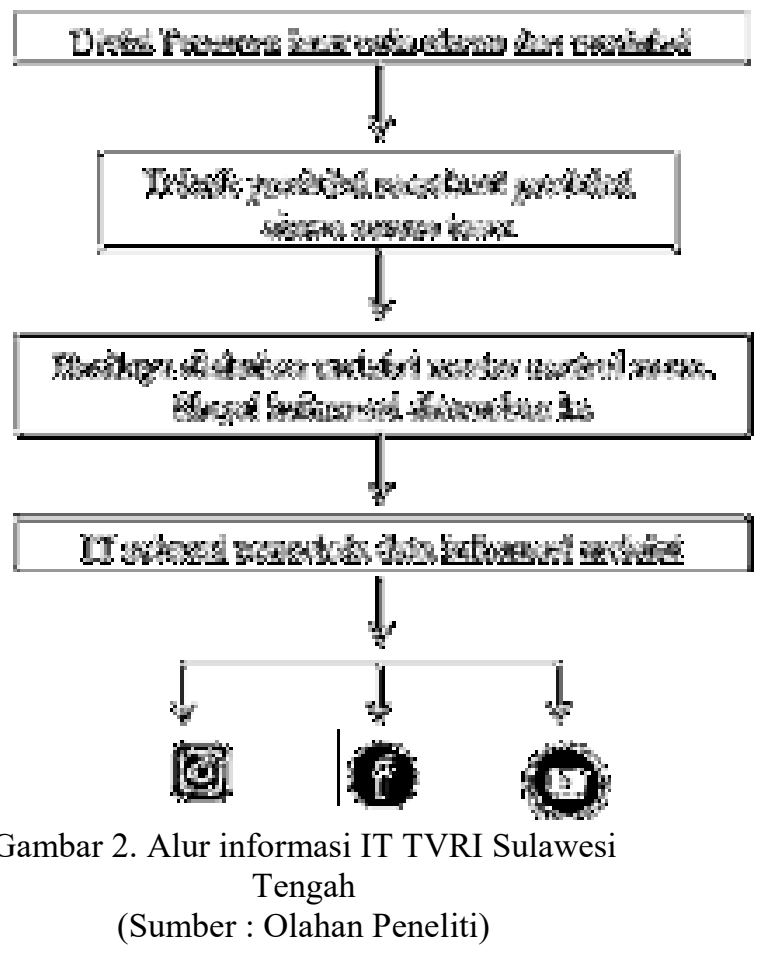

\section{Hasil dan Pembahasan}

Berdasarkan hasil penelitian yang diperoleh dari hasil wawancara bersama informan yang dikaitkan dengan teori Philips dan Young bahwa pengelolaan cyber PR TVRI Sulteng terhadap stakeholders internal umumnya sudah menerapkan adanya transparansi jenis radical transparency yaitu metode manajemen dimana seluruh data, argument dan hal terkait pergerakan dan keputusan perusahaan disebarkan ke publik internal perusahaan TVRI Sulteng.

Semua data yang berkaitan tentang perusahaan itu pertama dikelola oleh level manajemen setelah dirapatkan dan diputuskan barulah disebarkan ke semua pegawai yang ada di perusahaan. Sedangkan empat teori dari Philips dan young yng terdiri dari internet porosity, internet as an agent, richness in content, dan reach lebih memfokuskan pada stakeholders eksternal.

Adapun dalam implementasinya, pengelolaan cyber PR TVRI Sulteng dalam memberikan informasi kepada stakeholders eksternal khususnya program acara 
tayangan harus menggunakan bahasa yang cukup jelas dan penjelasan-penjelasannya yang berpedoman pada undang-undang penyiaran seperti ketika ada program lokal atau daerah yang dikirim baik facebook, instagram dan youtube pasti memuat penjelasan terkait konten apa yang disebarkan tersebut. Pelaksanaan ini dianggap bahwa TVRI Sulteng telah melakukan transparansi dengan cara pengunggahan berbagai konten yang mudah dipahami oleh semua kalangan dan bisa diakses publik dengan mudah.

Seperti yang diungkapkan Philips dan Young (2009: 37) yang mengatakan bahwa transparansi itu adalah sesuatu yang hidup dan berjalan baik yang mana perusahaan diajak untuk semakin transparan dalam memberikan informasi kepada stakeholders lewat media sosial. Sama halnya dengan TVRI Sulteng sebagai perusahaan media yang sudah menggunakan cyber PR di era digital seperti sekarang ini telah menggunakan jenis controlled transparency atau sebuah transparansi dimana perusahaan mengirimkan informasi kepada stakeholders secara terkontrol.

Temuan lainnya bahwa di dalam kegiatan cyber PR dengan menggunakan beberapa media online yang telah dipilih terdapat beberapa konten yang terlihat yakni mayoritas iklan tayangan program acara, info grafik terkait covid 19 tetapi saat ini kurang diupdate, dan video. Mengacu pada teori Philips dan Young (2009:55) yang menjelaskan bahwa kekayaan informasi online salah satunya harus memiliki penciptaan konten yang kaya artinya adanya berbagai macam bentuk konten seperti katakata, gambar, suara, video, diagram, musik, dan lain-lain.

Lain halnya di TVRI Sulteng yang hanya menggunakan beberapa bentuk saja yaitu gambar, infografik, dan video ini kemudian dinilai bahwa richness in content atau kekayan informasi sudah dijalankan oleh TVRI Sulteng tetapi dalam pelaksanaan dan pengelolaannya dinilai belum maksimal.

Berdasarkan uraian wawancara dan hasil observasi temuan lain juga ditemukan oleh peneliti terkait konsep cyber PR yang kelima yaitu reach atau jangkauan publik seperti yang dijelaskan oleh Philips dan (Young 2009:56) dimana perusahaan bisa melakukan beberapa teknik agar halaman website perusahaan dapat dengan mudah ditemukan oleh publik, seperti dengan search engine optimization dan hyperlink exchange, dalam hal ini TVRI Sulteng menyediakan menu atau tombol tersebut di dalam website www.tvrisulteng.com. Upaya dalam menjangkau audiens yang dilakukan oleh TVRI Sulteng melalui tiga (3) media sosial yaitu youtube, instagram dan facebook menunjukkan hasil yang positif.

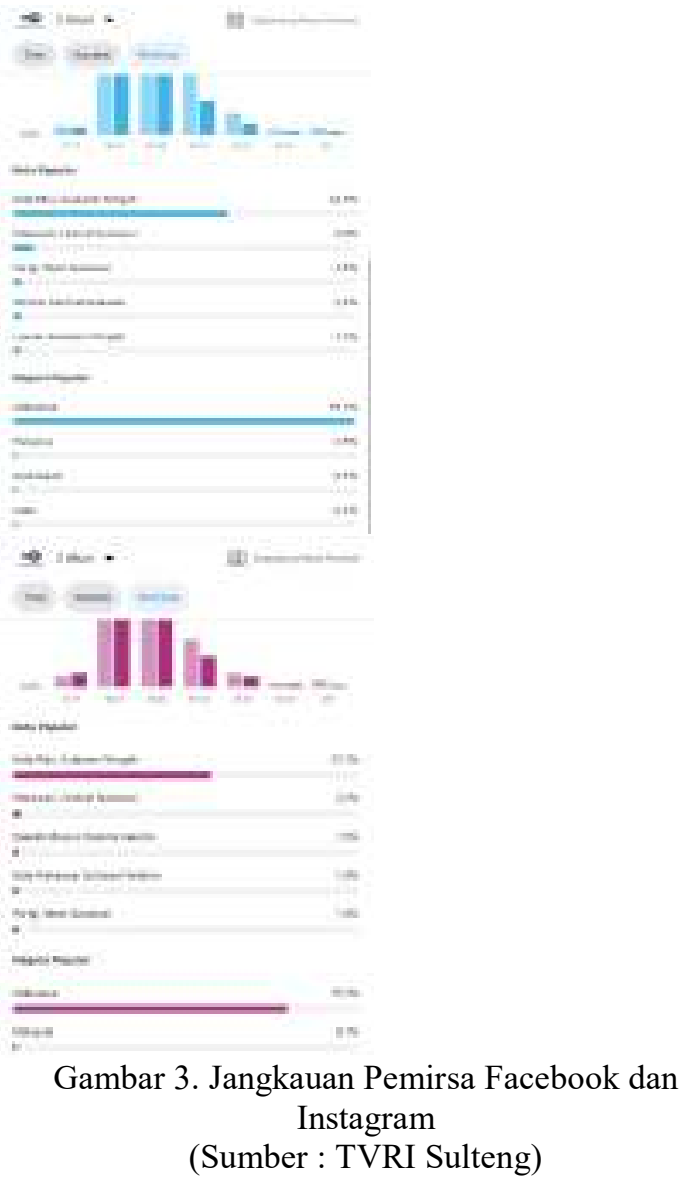

KINESIK Vol. 8 No. 1 (2021) | 48 
Penerapan cyber PR dengan menambah media komunikasi menjadi salah satu upaya TVRI Sulteng dalam menjalin relasi yang lebih luas terhadap audiens. Seperti kita ketahui bersama bahwa TVRI secara umum telah berupaya bertransformasi melalui konvergensi media sebagai upaya menyesuaikan diri terhadap perkembangan teknologi baru dan media baru (Arif Pujo Suroko, 2020).

Menjadi lembaga penyiaran milik negara membuat TVRI termasuk TVRI Sulteng harus menjaga nama baik atau reputasi baik secara offline dan online. Saluran televisi plat merah, TVRI, mencatatkan sejarah baru dengan mengambil langkah transformasi menuju media dengan budaya konten positif untuk Indonesia dan kancah internasional. Tidak sekadar berubah wajah dan seragam, momen perubahan ini juga dilakukan untuk merubah budaya kerja dan budaya organisasi serta membuat TVRI lebih dekat dengan generasi milenial (kumparan.com).

Pemaparan sebelumnya menunjukkan bahwa TVRI Sulteng berusaha menerapkan dan menjaga konsep 3R yaitu menjalin Relation, demi menjaga Reputasi serta melakukan transformasi guna menciptakan Relevansi dengan target publik korporat. Sedangkan untuk website dan twitter hasil jangkauannya belum semaksimal media sosial yang lain karena keterbatasan SDM (Sumber Daya Manusia) dalam pengelolaannya.

Terlepas dari belum maksimalnya pemanfaatan media sosial oleh PR/Humas TVRI Sulteng akibat kendala dan keterbatasan tersebut, namun upaya yang telah dilakukan sejalan dengan definisi e-PR yaitu inisiatif PR yang menggunakan media internet sebagai sarana publisitas (Basit \& Rahmawati, 2017:202), dalam hal ini menyebarkan informasi terkait program acara TVRI Sulteng.

\section{Kesimpulan}

Berdasarkan hasil penelitian dan pembahasan yang telah dianalisis secara sistematis dan didukung oleh data-data yang diperoleh di lapangan maka dapat disimpulkan bahwa PR / Humas TVRI Sulteng secara internal telah menerapkan konsep radical transparency. Penerapan konsep tersebut terlihat dari pemanfaatan media komunikasi internal melalui whatsapp dan email yang dinilai lebih efektif dan intensif dalam berbagi informasi utamanya di masa pandemi. Selain itu, informasi yang disebarkan jika terkait kebijakan strategis dan kompetisi bisnis yang bersifat rahasia hanya disebarkan secara internal perusahaan. Sedangkan dalam menjangkau stakeholders eksternal yang pertama menggunakan transparansi jenis controlled transparency yaitu informasi yang disebarkan oleh perusahaan ke publik elalui internet dilakukan secara terkontrol dimana tayangan yang disebarkan ke media sosial TVRI Sulteng melalui proses filterisasi ataupun penyaringan tayangan dengan tidak menyinggung tentang SARA (Suku, Agama, Ras, dan Antargolongan). Kedua, Richness in content yaitu kekayaan konten yang terdiri dari dua yaitu penciptaan konten yang kaya berupa kata-kata, gambar, suara, video, diagram, musik dan lain-lain disediakan untuk public. Terkait hal tersebut konsep ini berusaha dijalankan oleh TVRI Sulteng tetapi dalam pelaksanaan dan pengelolaannya dinilai belum maksimal akibat keterbatasan SDM (Sumber Daya Manusia). Ketiga, Reach berarti jangkauan publik dimana TVRI Sulteng berupaya memperluas jangkauan penonton dengan mengaktifkan beberapa media sosialnya yaitu facebook, intagram, youtube, website, dan twitter. Meluasnya jangkauan dari semula hanya tiga (3) wilayah yaitu Palu, Sigi dan Donggala 
dengan adanya internet TVRI Sulteng dapat menjangkau audiens yang lebih luas. Selain itu TVRI Sulteng juga menyediakan hyperlink exchange dan search engine optimization untuk memudahkan mengakses website.

Sementara itu dua konsep cyber PR tidak ditemukan pada penelitian ini. Konsep tersebut yaitu internet porosity, karena semua informasi yang disebarkan kepada stakeholders ekternal haruslah sesuai dengan UU penyiaran sebagai pedoman TVRI Sulteng sehingga semua informasi mengenai perusahaan tidak mudah bocor. Kedua yaitu internet as an agent, konsep ini belum diterapkan terlihat setiap posting-an pada lima media sosial TVRI Sulteng kurang diminati oleh masyarakat (terlihat dari jumlah komen dan suka terbilang sedikit) dan peneliti belum melihat adanya konten atau pesan yang kemudian memberikan pemahaman baru terhadap stakeholders eksternal.

\section{Referensi}

Daymon Christine, Holloway Immy. 2008. Metode-metode Riset Kualitatif Dalam Public Relations and Marketing Communications. Yogyakarta: PT Bentang Pustaka

Gani, P.K. 2015. PR Corner. Jakarta: PT. Gramedia

Hairunnisa. 2015. PUBLIC RELATIONS. Yogyakarta: Graha Ilmu.

Kasali, Rhenald. 1994. Manajemen Public Relations Konsep dan Aplikasinya di Indonesia. Jakarta: Pustaka Utama Grafiti
McQuail, Denis. 2010. Teori Komunikasi Massa McQuail Edisi 6. Jakarta: Salemba Humanika

Phillips, David and Philip Young. 2009. Online Public relationss A practical guide to developing an online strategy in the world of social media, Second Edition, London and Philadelphia

Ruslan, Rosady. 2007. Kiat dan Strategi Kampanye Public Relations. Ed. Revisi 5. Jakarta: PT. Raja Grafindo Persada

Ardianto, Elvinaro. 2010. Metodologi Penelitian Untuk Public Relations Kuantitatif dan Kualitatif. Bandung: Remaja Rosdakarya

Elvinaro. Ardianto. 2008. Public Relation: Pendekatan Praktis untuk Menjadi Komunikator, orator, presenter dan juru Kampanye yang Handal. Bandung: Widya Padjajaran.

Kriyantono, Rahmat. 2006. Teknik Praktis Riset Komunikasi: Disertai Contoh Praktis Riset Media, Public Relations, Adversting, Komunikasi Organisasi, Komunikasi Pemasaran . Jakarta: Prenada Media Group

Rumanti, M. A. 2002. Dasar-dasar Public Relation Teori dan Praktik. Jakarta: Penerbit PT. Grafindo.

Basit, Abdul \& Rahmawati Tri. 2017. Cyber Public Relations (E-PR) dalam 
Brand Image Wardah Kosmetik dengan Pedekatan Mixed Method. Jurnal. Tanggerang: Ilmu Komunikasi FISIP Universitas Muhammadiyah Tanggerang. https://jurnal.umt.ac.id/index.php/ny imak/article/view/483 (diakses 06 September 2020, pukul 21.52 WITA)

Kumparan.com.2019.Transformasi TVRI agar Lebih Dekat dengan Milenial. https://kumparan.com/swaonline/transf ormasi-tvri-agar-lebih-dekat-denganmilenial-1qqZA0H9837/full (diakses pada tanggal 244 Maret 2021, pukul 23.21 Wita)

Putri, D. 2019. Strategi Cyber Public Relations Hartono Lifestyle Mall Solo Baru Dalam Meningkatkan Traffict Pengunjung Mall. Skripsi. Surakarta: Jurusan Komunikasi dan Penyiaran Islam IAIN Surakarta. http://eprints.iainsurakarta.ac.id/4784 (diakses 02 Agustus 2020, pukul 22.28 WITA)

Sumarto, R. H. 2016. Komunikasi Dalam Kegiatan Public Relations. Jurnal. Yogyakarta: Universitas Negeri Yogyakarta. https://journal.uny.ac.id/index.php/i nformasi/article/view/9650 (diakses 25 September 2020, pukul 20.13 WITA)

Suroko, Arif Pujo. 2020. Transformasi Lembaga Penyiaran Publik (Lpp) Televisi Republik Indonesia (Tvri) Di Era Konvergensi Media. Tesis. Surakarta: Universitas Sebelas Maret. https://digilib.uns.ac.id/dokumen/deta il/75491/Transformasi-LembagaPenyiaran-Publik-Lpp-TelevisiRepublik-Indonesia-Tvri-Di-Era-
Konvergensi-Media (diakses pada 23 Maret 2021, pukul 144.34 Wita)

Anwar, R. (2015). Peran Praktis Public Relations Dalam OrganisasiOrganisasi Di Yogyakarta. Jurnal AnNida, 7(1), 46-55.

Aprilia, P., Hafiar, H., \& Subekti, P. (2020). Fungsi public relations pada strategi merek Inspira TV dalam membangun brand perusahaan. ProTVF, 4(1), 20-41.

Ardianto, E. (2008). Public Relation: Pendekatan Praktis untuk Menjadi Komunikator, orator, presenter dan juru Kampanye yang Handal.

Basit, A., \& Rahmawati, T. H. (2017). Cyber Public Relations (E-PR) dalam Brand Image Wardah Kosmetik dengan Pedekatan Mixed Method. Nyimak (Journal of Communication), 1(2), 197-208. https://doi.org/10.31000/nyimak.v1i2. 483

Budhi, G. S. (2016). Analisis Sistem ECommerce Pada Perusahan Jual-Beli Online Lazada Indonesia. Elinvo (Electronics, Informatics, and Vocational Education), 1(2), 78-83. https://doi.org/10.21831/elinvo.vli2.1 0880

Daymon Christine, H. I. (2008). Metodemetode Riset Kualitatif Dalam Public Relations and Marketing Communications.

Gani, P. . (2015). PR Corner.

Hairunnisa. (2015). PUBLIC RELATIONS.

Kasali, R. (1994). Manajemen Public 
Relation: konsep dan aplikasinya di Indonesia.

McQuail, D. (2010). Teori Komunikasi Massa McQuail Edisi 6.

Rumanti, M. A. (2002). Dasar-dasar Public Relation Teori dan Praktik.

Ruslan, R. (2007). Kiat dan Strategi Kampanye Public Relations.

Sukoco, I. (2014). Fungsi Public Relations Dalam Menjalankan Aktivitas Corporate Social Resposibility. Jurnal
Dinamika Manajemen, 4(2), 188-198. https://doi.org/10.15294/jdm.v4i2.276 2

Sumarto, R. H. (2016). Komunikasi Dalam Kegiatan Public Relations. Informasi, 46(1), 63.

https://doi.org/10.21831/informasi.v46 i1. 9650

Yuliawati, \& Irawan, Pera, E. (2016). Peran Cyber Public Relations Humas Polri Publik Secara Online. Jurnal Politikom Indonesia, 1(1), 1-13. 